\title{
Milk matters: offspring survival in Columbian ground squirrels is affected by nutrient composition of mother's milk
}

\author{
Amy L. Skibiel ${ }^{\dagger}$ and Wendy R. Hood ${ }^{*}$ \\ Department of Biological Sciences, Auburn University, Auburn, AL, USA
}

Through maternal effects, information about environmental conditions experienced in the maternal generation can be transmitted to subsequent generations. Although maternal effects have been described and quantified in many mammalian species, the underlying causal links are often under-studied. The close association between mother and neonate during the extended period of lactation in mammals provides a unique opportunity for mothers to influence offspring phenotype through nutrient provisioning of milk. The purpose of this study was to examine sources of inter-individual variation in milk composition and impacts on offspring phenotype and survival. Variation in fat content, protein content, and energy density of mother's milk was associated with timing of reproduction. Mothers with intermediate birthdates produced milk that was higher in fat and energy density, but lower in protein than females with early or late birthdates. In turn, the pattern of change in milk composition affected juvenile overwinter survival. The protein content of Columbian ground squirrel milk typically increases to peak lactation and then declines before weaning. Pups consuming milk that was lower in protein in early lactation but then relatively high in protein at peak and late lactation had a higher probability of survival overwinter. Our results indicate that the interplay between the timing of reproduction and lactation performance has consequences for maternal and offspring fitness.

Department of Animal Sciences, University of Florida, Gainesville, FL,

Specialty section:

This article was submitted to Behavioral and Evolutionary Ecology, a section of the journal

Frontiers in Ecology and Evolution

Received: 09 July 2015 Accepted: 14 September 2015 Published: 06 October 2015

Citation: Skibiel AL and Hood WR (2015) Milk matters: offspring survival in

Columbian ground squirrels is affected by nutrient composition of mother's milk. Front. Ecol. Evol. 3:111. doi: 10.3389/fevo.2015.00111

Keywords: maternal effects, milk composition, timing of reproduction, body condition, lactation, Urocitellus columbianus

\section{Introduction}

Environmental conditions in the maternal generation can have substantial impacts on offspring phenotype, independent of additive genetic effects. These maternal effects are ubiquitous in nature occurring across many taxa from maternal influences on seed mass and dispersal patterns in plants (Donohue and Schmitt, 1998) to the impact of maternal rank on offspring growth and age at reproductive maturity in mammals (reviewed in Holekamp and Dionak, 2009). In mammals, these effects can occur through two broad mechanisms- nutritionally, via food provisioning and nutrient transfer across the placenta or through milk, and non-nutritionally, through maternal care behaviors and the transfer of non-nutritive substances, such as antibodies or hormones, from mother to young. Through these means, maternal effects contribute to transgenerational phenotypic plasticity whereby offspring phenotype can be modified in response to 
prevailing environmental conditions in the maternal generation (Fox and Mousseau, 1998). Maternal effects can also have a genetic component upon which natural selection can act and thus, can be important forces in adaptation to new environmental conditions and in the evolutionary dynamics of populations (Kirkpatrick and Lande, 1989; Lande and Kirkpatrick, 1990; Wolf et al., 1998).

Maternal effects in mammals are especially prevalent because of the extended period of offspring nutritional dependence during gestation and lactation (Maestripieri and Mateo, 2009). Postnatally, milk provides young with the building blocks required to support tissue growth prior to independence from the mother (Robbins et al., 1981). Undernutrition during early postnatal life can retard neural, skeletal, and organ development and can have negative effects on offspring physiology into adulthood (de Souza and Moura, 2000; Prentice, 2004; de Moura and Passos, 2005; McMillen and Robinson, 2005). As a result, offspring fitness is likely to be at least partly dependent on a female's ability to deliver adequate nutrients and energy through milk (Robbins et al., 1981).

The reproductive performance of mothers, measured as offspring growth, offspring mass, litter size, or offspring survival, has been shown to vary with maternal characteristics, such as age, parity, body condition, and body size, as well as reproductive timing (Clutton-Brock et al., 1982; Hoogland, 1995; Skibiel et al., 2009). Larger females in better condition tend to invest more resources into reproduction (Price, 1998; Broussard et al., 2005), either producing more young or heavier individual young. In addition, for seasonal breeders, females breeding earlier within the reproductive period tend to have greater reproductive success (Dobson and Michener, 1995; Rieger, 1996; Huber et al., 1999; Neuhaus, 2000a). Breeding earlier may be advantageous due to reduced competition among females for high quality food sources (Clutton-Brock et al., 1982) or it may afford females more time to gain somatic stores in preparation for subsequent breeding attempts (Cohen, 1976).

Despite the plethora of studies addressing patterns of reproductive investment in both ecological and evolutionary contexts, relatively little is known about the underlying links between variation in maternal traits, reproductive timing, and reproductive performance. Nevertheless, there is some evidence that a mother's somatic tissue stores can impact the amount of nutrients she transfers to her young through milk. Milk composition has been shown to vary with maternal body mass or condition in humans (Homo sapiens; Nommsen et al., 1991; Dewey, 1997), Subantarctic fur seals (Arctocephalus tropicalis; Georges et al., 2001), rhesus macaques (Macaca mulatta; Hinde, 2007b), Iberian red deer (Cervus elaphus hispanicus; Landete-Castillejos et al., 2005), common marmosets (Callithrix jacchus; Tardif et al., 2001), mares (Equus ferus caballus; Doreau et al., 1992), and gray seals (Halichoerus grypus; Mellish et al., 1999). In turn, the composition of milk, especially fat and protein content, has been demonstrated to have positive impacts on the postnatal growth rate and body mass of suckling young (Iverson et al., 1993; Mellish et al., 1999; Tardif et al., 2001; Landete-Castillejos et al., 2003b).
In this study, we assess factors that contribute to variation in the composition of mother's milk and the impacts of milk composition on offspring size, growth, and survival in the Columbian ground squirrel, Urocitellus columbianus. This is an ideal species for studying sources of variation in milk composition and impacts on offspring, (1) because all individuals in the population can be observed throughout the active season and upon emergence the following spring so survival through hibernation can be determined and (2) given this species' interesting ecology, milk composition may be an important factor determining juvenile survival overwinter. Columbian ground squirrels are obligate hibernators that do not cache food overwinter; thus, nutrient acquisition and fat deposition prior to hibernation is critical to overwinter survival. Unlike other hibernators, such as bats and bears, which begin hibernating several months after weaning the young (Powell et al., 1997; Racey and Entwistle, 2000), adult female Columbian ground squirrels begin hibernating a few weeks after weaning their pups (Young, 1990). After birth, pups consume only the mother's milk during the 4-week lactation period (Murie, 1992). In populations at lower elevations (such as the one studied herein), parturition occurs near the end of May (Skibiel et al., 2013) and pups are thus weaned around the end of June. Adult females enter hibernation in early August (Young, 1990; Dobson et al., 1992; Neuhaus, 2000a), thus young are weaned approximately 6 weeks before the 8-9 month hibernation commences. Under these conditions, the nutritional composition of milk consumed by young is expected to be imperative for their growth and survival. Therefore, interactions between maternal and offspring phenotype through lactation performance are expected to be especially pronounced in this species.

Although, Columbian ground squirrels are typically considered to be income breeders, relying predominantly on ingested resources to support energy needs for reproduction (Drent and Daan, 1980; Jönsson, 1997), somatic energy stores are also important resources for reproductive investment (Broussard et al., 2005). Indeed, previous studies of Columbian ground squirrels have shown that maternal body size and body condition, as well as reproductive timing, impact reproductive performance (King et al., 1991; Dobson et al., 1999; Skibiel et al., 2009). Larger mothers in better condition produce either more young or young that are heavier and grow faster during the lactation period (King et al., 1991; Dobson et al., 1999; Skibiel et al., 2009), and mothers that reproduce earlier have more of their young survive hibernation (Dobson et al., 1999). If these relationships are mediated through the nutritive properties of mother's milk, the levels of milk protein and fat and milk energy density should be particularly important for offspring growth and survival. Columbian ground squirrels in populations supplemented with high protein feed have higher juvenile survival rates overwinter and are heavier than individuals in un-supplemented populations (Dobson and Kjelgaard, 1985). Furthermore, because this species fasts during hibernation, consumption of polyunsaturated fatty acids and deposition of internal fat stores during the active season are critical to meet energy needs during hibernation (Tahti, 1978; Serkova et al., 2007). For these reasons, we predicted that larger mothers, 
mothers in better condition, and/or mothers that reproduce earlier in the season would produce higher quality milk (i.e., greater concentrations of fat and protein, as these nutrients contribute most to growth in mass, and higher energy density for fueling cellular processes involved in tissue and organ development). Furthermore, we predicted that mothers that provision young with high protein, high fat, and energydense milk would produce young with faster growth rates, higher weaning masses, and a greater probability of survival overwinter. We also analyzed changes in the concentration of milk components from early to peak lactation and from peak to late lactation in order to elucidate effects of temporal variation on offspring performance. We have previously shown that the concentration of most milk constituents increases from early to peak lactation (19 days postpartum) and then decreases from peak to late lactation ( 25 days postpartum), although there is substantial variation in temporal patterns among mothers (Skibiel and Hood, 2013).

\section{Materials and Methods}

\section{Field Work}

We studied a population of Columbian ground squirrels

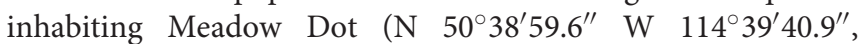
elevation $1565 \mathrm{~m}$ ) in the Sheep River Provincial Park (Alberta, Canada) in 2009. All squirrels were captured upon emergence from overwinter hibernacula with Tomahawk Live Traps (Tomahawk \#201 collapsible chipmunk trap, $48 \times 15 \times 15 \mathrm{~cm}$, Tomahawk, Wisconsin, USA) baited with a small amount of peanut butter. We tagged animals with fingerling eartags containing a unique number for permanent identification, we weighed them with a spring-loaded scale (Pesola Ag, Baar, Switzerland) to the nearest $5 \mathrm{~g}$, and we measured zygomatic arch breadth using dial calipers (Swiss Precision Instrument, Garden Grove, California, USA) to the nearest $0.01 \mathrm{~mm}$. Animals were also painted with a unique marking on their backs using black hair dye (Lady Clairol Hydrience \#51 Black Pearl; Proctor and Gamble, Stamford, CT, U.S.A.) in order to observe individuals from a distance. Mating dates of all adult females were determined by examining reproductive morphology and through observations of mating behavior. Twenty-four days were added to the known mating date to estimate parturition date (Shaw, 1925; Murie and Harris, 1982).

Two to three days before the estimated parturition date, we captured the adult females and transported them to the laboratory at the field station approximately $0.75 \mathrm{~km}$ from the field site. Animals were housed individually in polycarbonate rat cages $\left(267 \times 483 \times 20 \mathrm{~mm}^{3}\right.$; Allentown Caging Equipment Company, Allentown, New Jersey, USA) containing pine chips and newspaper and covered in vented black plastic to reduce stress. Dams were maintained on horse feed (EQuisine sweet show horse ration, Unifeed, Okotoks, Alberta, Canada) ad libitum and lettuce and apple fed twice daily as the sole water source. We checked cages 3-4 times per day for visual signs of neonates. Approximately $6 \mathrm{~h}$ following first observation of pups in the cage, initial post-partum measurements and records were taken. This included dam mass (to the nearest $5 \mathrm{~g}$ ) and offspring
TABLE 1 | Total number of dams milked and number of milk samples assayed for proximate composition at each lactation stage.

\begin{tabular}{lccccc}
\hline & \multicolumn{5}{c}{ Lactation Stage } \\
\cline { 2 - 6 } & $\begin{array}{c}\mathbf{4} \text { days } \\
\text { pp }\end{array}$ & $\begin{array}{c}\mathbf{9} \text { days } \\
\text { pp }\end{array}$ & $\begin{array}{c}\mathbf{1 4} \text { days } \\
\text { pp }\end{array}$ & $\begin{array}{c}\mathbf{1 9} \text { days } \\
\text { pp }\end{array}$ & $\begin{array}{c}\mathbf{2 5} \text { days } \\
\text { pp }\end{array}$ \\
\hline Dams milked & 35 & 31 & 29 & 28 & 28 \\
Milk fat & 31 & 30 & 29 & 28 & 28 \\
Milk protein & 32 & 30 & 29 & 28 & 28 \\
Milk sugar & 33 & 31 & 29 & 28 & 28 \\
Milk energy & 30 & 30 & 29 & 28 & 28
\end{tabular}

Thirty six dams gave birth. 8 dams suffered whole litter loss and an additional 6 dams suffered partial litter loss during the lactation period. Volume of milk collected from a mother at a given lactation stage was not always enough to assay for all proximate components. $P P=$ postpartum.

mass (to the nearest $0.001 \mathrm{~g}$ ) and sex. For identification purposes, we removed a small portion of tissue from the outer toe bud of the left or right hind foot of all neonates. Mother and pups were released back on the meadow to their natal burrows 1-2 days postpartum.

We captured all dams and juveniles when the litters emerged from the natal burrow around the time of weaning (approximately 27 days postpartum; Murie, 1992). Juveniles were weighed (to the nearest $0.01 \mathrm{~g}$ ), tagged, and marked as for the adults earlier in the spring. Survival of juveniles overwinter was determined based on emergence the following spring. Columbian ground squirrels exhibit male-biased dispersal, which does not occur until after the first hibernation (Boag and Murie, 1981; Murie and Harris, 1984; Dobson and Murie, 1987). Thus, juveniles that did not emerge the following spring were assumed to have died during the hibernation period.

\section{Milk Collection and Analysis}

We collected milk approximately every 5 days postpartum $(4,9$, 14,19 , and 25 days postpartum; hereafter referred to as lactation stage). Overall 36 dams were milked; however, 8 mothers lost their whole litter during the lactation period. The percent of whole litters lost in this study is within the range of previous reports for this species (11-40\% of litters, Murie et al., 1998; 44$62 \%$, Neuhaus, 2000b; 23\%, Skibiel et al., 2013). For 28 dams, milk samples were collected at all 5 time points. However, sample volumes were not always large enough to assay for all milk constituents at each time point (Table 1). Dams were captured on the meadow and held for $3 \mathrm{~h}$ prior to milk collection to allow milk accumulation within the gland. Dams were anesthetized with isoflurane, the nipples were cleaned, and oxytocin (Osborn, Bimeda Inc, Oakbrook Terrace, IL, concentration $=20$ USP per $\mathrm{ml}$, dose $=0.5 \mu \mathrm{l} / \mathrm{g}$ ) administered to stimulate milk letdown. Milk was expressed by light manual palpation, transferred to screw top vials, and stored at $-80^{\circ} \mathrm{C}$ until analyses could be completed.

We assayed milk for proximate composition (i.e., fat, protein, and sugars) following methods for micro volumes of milk (Hood et al., 2009; Skibiel and Hood, 2013). Briefly, dry matter was determined by drying to constant mass, total lipid by micromodification of the Roese-Gottlieb method, sugar content with 
the phenol-sulfuric acid method and crude protein by $\mathrm{CHN}$ elemental analysis. Milk energy density was estimated from energy equivalents of proximate components of cow's milk as in Derrickson et al. (1996). All data on proximate milk composition are presented herein as $\mathrm{mg} / \mathrm{g}$ or $\mu \mathrm{g} / \mathrm{g}$ of milk (wet mass) whereas energy density is expressed as $\mathrm{kcal} / \mathrm{g}$. All research methods used in this study were approved by the Auburn University Institutional Animal Care and Use Committee, protocol number 2009-1151 and the University of Calgary Life and Environmental Sciences Animal Care Committee, protocol BIO 9R-42.

\section{Variables}

Milk composition was examined relative to maternal characteristics including structural size, body condition, and timing of reproduction. Zygomatic arch breadth, measured at spring emergence from hibernation, was used as an estimate of structural size. Litter birthdate (day of the year; 1 January = day 1) was used as a measure of reproductive timing. Maternal body condition at spring emergence was estimated by extracting the residuals from the regression of spring emergence body mass on zygomatic arch breadth (Dobson et al., 1999; Georges et al., 2001; Schulte-Hostedde et al., 2005; Skibiel et al., 2009). Measures of offspring performance included offspring body mass at weaning, growth rate during the lactation period and survival overwinter. Growth rate was calculated by subtracting mass at birth from mass at weaning and dividing by lactation duration to yield mass gain in grams per day. Temporal patterns in milk composition were calculated as the change in milk composition from early to peak lactation and from peak to late lactation. Therefore, changes in milk composition are an estimate of the concentration of a milk constituent at one stage of lactation (either early, peak, or late) relative to other stages. Change in milk composition from early to peak lactation was calculated as the concentration of the milk constituent at day 19 postpartum minus the concentration of the milk constituent at day 4 postpartum divided by 15 days. Change in milk composition from peak to late lactation was calculated as the concentration of the milk constituent at day 25 postpartum minus the concentration of the milk constituent at day 19 postpartum divided by 6 days. Change for both time periods is expressed as $\mathrm{mg} / \mathrm{g}$ per day (for change in fat and protein), $\mu \mathrm{g} / \mathrm{g}$ per day (for change in sugar), or $\mathrm{kcal} / \mathrm{g}$ per day (for change in energy density).

\section{Statistics}

SAS statistical software (SAS, 2002) was used to run all statistical analyses. Shapiro-Wilk tests were employed to determine if data were normally distributed. To examine effects of maternal characteristics and litter birthdate on milk composition (e.g., protein, fat and sugar concentration and energy density), we used separate general linear mixed models (PROC MIXED) for each milk component, including dam ID as a repeated measure $($ REPEATED $=$ lactation stage/SUB $=$ dam ID) and employing a compound symmetric covariance structure. In addition, for each milk component, general linear models (PROC GLM) were used to assess the effects of litter birthdate, maternal size, and maternal body condition on temporal patterns of milk composition within females. Prior to running the above models, we first plotted each maternal characteristic against the milk constituents to visually assess linearity of the relationships. Litter birthdate appeared to exhibit a curvilinear relationship with milk composition and thus litter birthdate was also included in the models as a squared term.

General linear mixed models (PROC MIXED) were used to examine impacts of the concentration of milk components and temporal patterns of milk composition on offspring weaning mass and growth rate. Separate models were run for each milk component. Because litter size at weaning is significantly negatively correlated to offspring weaning mass and growth rate in this population (Skibiel et al., 2009), litter size was included as a covariate in the models. Dam ID was included as a random effect to account for the multiple pups per dam.

Logistic regression (PROC LOGISTIC) was used to examine effects of the concentration of milk components and daily changes in milk composition (each milk constituent run separately) on the probability of individual pups surviving overwinter. In models of survival as the response variable, we did not control for multiple pups within dam because only 2 dams had more than 1 of their pups survive overwinter. Alphalevel was 0.05 for all statistical analyses. Averages presented throughout are mean \pm standard error of the mean.

\section{Results}

Maternal mass at spring emergence was positively associated with zygomatic arch breadth $\left(R^{2}=0.69, n=36\right.$, $P<0.0001)$. Residuals extracted from these regressions were normally distributed ( $W=0.98, n=36, P=0.53$ ) and thus were used as an estimate of body condition. Mean milk fat concentration was $89.5 \pm 2.5 \mathrm{mg} / \mathrm{g}$, sugar was $30 \pm 0.90 \mu \mathrm{g} / \mathrm{g}$, protein was $92.5 \pm 2.3 \mathrm{mg} / \mathrm{g}$ and milk energy density was $1.5 \pm$ $0.2 \mathrm{kcal} / \mathrm{g}$.

Mean litter birthdate was day $145 \pm 0.82$ corresponding to a date of 25-May (range: 17-May-1-June). There was a significant relationship between litter birthdate and milk fat concentration [litter birthdate: $F_{(1,28)}=7.69, P=0.01$; litter birthdate ${ }^{2}$ : $\left.F_{(1,28)}=7.77, P=0.01\right]$, such that mothers with intermediate litter birthdates had the highest milk fat content (Figure 1A). There was also a significant relationship between litter birthdate and energy density of milk [litter birthdate: $F_{(1,28)}=11.42$, $P=0.002$; litter birthdate $\left.{ }^{2}: F_{(1,28)}=11.47, P=0.002\right]$ and between litter birthdate and milk protein concentration [litter birthdate: $F_{(1,29)}=4.56, P=0.04$; litter birthdate ${ }^{2}$ : $F_{(1,29)}=4.49, P=0.04$; Figure 1B]. Litter birthdate did not have a significant impact on the concentration of sugar in milk [litter birthdate $F_{(1,29)}=0.88, P=0.36$; litter birthdate ${ }^{2}$ : $\left.F_{(1,29)}=0.84, P=0.37\right]$. Maternal condition and maternal size did not have significant effects on the concentration of any proximate milk constituent or milk energy density (all $P>0.05$ ). Milk composition varied with lactation stage; the magnitude and direction of these relationships are reported elsewhere (Skibiel and Hood, 2013). Maternal condition, maternal size, and litter birthdate did not have significant effects on the change in any milk constituent ( $P>0.05$ for all models; Table 2$)$. 

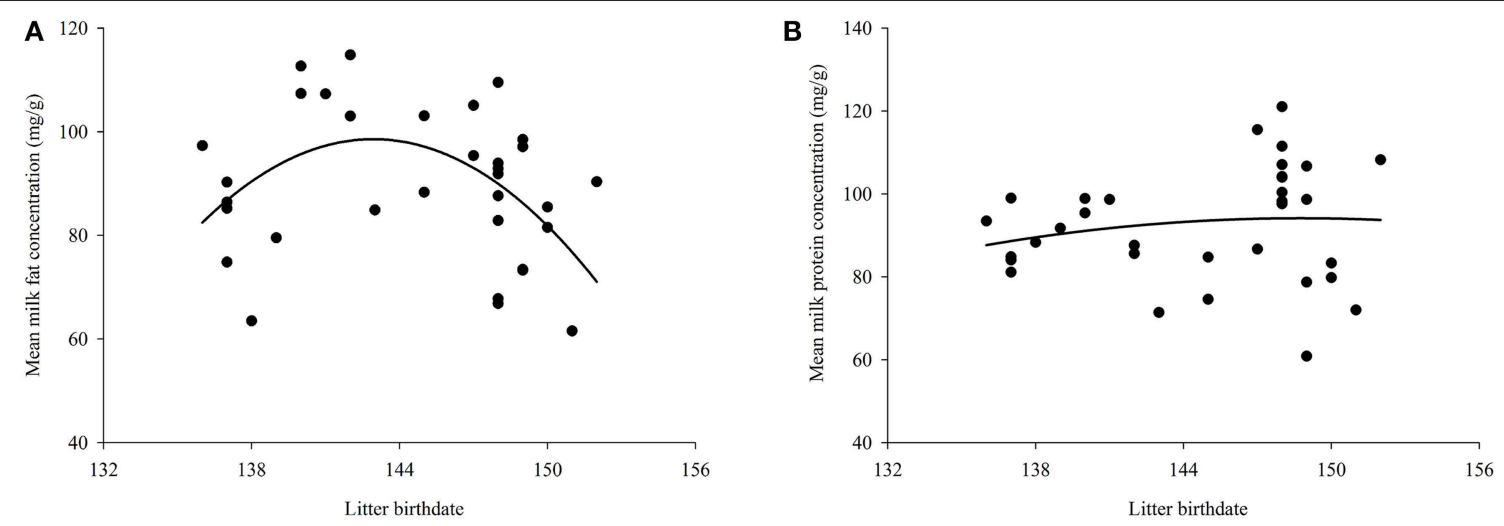

FIGURE 1 | Effect of litter birthdate on (A) milk fat concentration and (B) milk protein concentration averaged across lactation for each mother. The relationship between milk energy and litter birthdate is similar to that for fat concentration and is therefore not presented here.

TABLE 2 | General linear models testing effects of maternal characteristics and litter birthdate on changes in milk composition from early to peak lactation and from peak to late lactation.

$$
N \quad \text { Mean change } \pm \mathrm{SE} \quad \mathrm{R}^{2} \quad \boldsymbol{F} \text {-value } P \text {-value }
$$

\begin{tabular}{lccccc}
\hline EARLY TO PEAK LACTATION & & & & \\
Fat (mg/g per day) & 26 & $0.46 \pm 0.41$ & 0.28 & 2.00 & 0.13 \\
Protein (mg/g per day) & 27 & $2.59 \pm 0.31$ & 0.05 & 0.29 & 0.88 \\
Sugar ( $\mu \mathrm{g} / \mathrm{g}$ per day) & 27 & $0.25 \pm 0.09$ & 0.04 & 0.24 & 0.91 \\
Energy (kcal/g per day) & 25 & $0.02 \pm 0.004$ & 0.19 & 1.21 & 0.34 \\
PEAK TO LATE LACTATION & & & & \\
Fat (mg/g per day) & 28 & $-1.37 \pm 0.66$ & 0.23 & 1.76 & 0.17 \\
Protein (mg/g per day) & 28 & $-1.33 \pm 0.84$ & 0.20 & 1.38 & 0.27 \\
Sugar ( $\mu \mathrm{g} / \mathrm{g}$ per day) & 28 & $0.95 \pm 0.28$ & 0.06 & 0.40 & 0.81 \\
Energy (kcal/g per day) & 28 & $-0.02 \pm 0.007$ & 0.11 & 0.75 & 0.57 \\
\hline
\end{tabular}

Explanatory variables included in the model were maternal size, maternal body condition, and litter birthdate (also included in the models as a squared term). Early lactation is considered to be day 4 postpartum, peak lactation is 19 days postpartum and late lactation is 25 days postpartum. P-values were considered statistically significant at an $\alpha$-level of 0.05 .

Postnatal growth rate of pups was on average $2.72 \pm 0.17 \mathrm{~g} / \mathrm{day}$ (range: $0.75-4.79 \mathrm{~g} /$ day) and mean body mass of pups at weaning was $86.4 \pm 4.59 \mathrm{~g}$ (range: $31.6-136.8 \mathrm{~g}$ ). Litter size was negatively correlated with offspring weaning mass and growth rate $(P<$ 0.006 for all models). After statistically controlling for effects of litter size, neither the concentration of milk constituents at specific time points nor the changes in milk composition had significant impacts on offspring growth rate or weaning mass ( $P>0.05$ for all models).

The proximate composition of milk and milk energy density did not have a significant impact on the probability of juvenile survival overwinter. Litter size at weaning also did not affect probability of juvenile survival. Regardless of milk composition and litter size, pups with earlier birthdates were more likely to survive through winter $(P<0.04$ for all models). Greater changes in milk fat and sugar concentration and energy density were also not associated with juvenile survival overwinter (Table 3). However, after controlling for litter birthdate and litter size, pups consuming milk with a greater increase in protein content from early to peak lactation and a lower rate of decline in protein from peak to late lactation were more likely to survive overwinter (Table 3, Figure 2).

\section{Discussion}

Maternal effects provide a means through which offspring phenotype can be adjusted to maternal condition and/or the environment the young are likely to experience (Gluckman et al., 2005; Wells, 2007). In mammals, maternal effects may be prevalent during postnatal life when mothers are provisioning offspring with milk. However, the impact of proximate milk composition on variation in offspring condition and survival, two important components of individual fitness, is relatively understudied. We hypothesized that milk composition would vary in relation to maternal traits, such as body size and body condition, and the timing of reproduction. Furthermore, we expected that milk composition would underlie previously described relationships between maternal condition, offspring condition at weaning, and offspring survival (Skibiel et al., 2009). Interestingly, milk composition did not vary with maternal condition at spring emergence and we found no effect of milk composition on offspring growth or mass at weaning. Nevertheless, milk composition impacted offspring survival, suggesting that milk is exerting effects through a mechanism that is independent of offspring condition.

\section{Maternal Characteristics and Milk Composition}

None of the milk constituents examined varied with maternal condition or size, suggesting that the relationship between body condition and size of Columbian ground squirrel mothers and offspring weaning mass described in Skibiel et al. (2009) is unlikely to be attributable to milk composition. Females that are larger and in better condition are expected to allocate more resources to reproduction (Price, 1998; Broussard et al., 2005), due to greater competitive ability to acquire high quality resources (Ralls, 1976) or due to greater internal stores of energy (Iverson et al., 1993). However, it is possible that larger mothers 
TABLE 3 | Effects of change in milk composition, reproductive timing, and litter size on the probability of juvenile survival overwinter.

\begin{tabular}{|c|c|c|c|c|c|}
\hline Variable & $d f$ & Survived $\bar{X} \pm \mathrm{SE}$ & Did not survive $\bar{X} \pm \mathrm{SE}$ & $x^{2}$ & $P$-value \\
\hline \multicolumn{6}{|l|}{ FAT $(N=74)$} \\
\hline Change early to peak lactation (mg/g per day) & 1 & $1.25 \pm 0.44$ & $-0.33 \pm 0.27$ & 2.78 & 0.09 \\
\hline Change peak to late lactation (mg/g per day) & 1 & $-1.69 \pm 0.70$ & $-1.45 \pm 0.40$ & 1.18 & 0.28 \\
\hline Litter size & 1 & $2.39 \pm 0.35$ & $2.43 \pm 0.23$ & 2.23 & 0.14 \\
\hline Litter birthdate & 1 & $141.83 \pm 1.06$ & $145.06 \pm 0.55$ & 4.80 & 0.03 \\
\hline \multicolumn{6}{|l|}{ PROTEIN (N = 79) } \\
\hline Change early to peak lactation (mg/g per day) & 1 & $2.34 \pm 0.33$ & $2.19 \pm 0.22$ & 5.71 & 0.02 \\
\hline Change peak to late lactation (mg/g per day) & 1 & $-0.004 \pm 0.72$ & $-1.15 \pm 0.47$ & 4.49 & 0.03 \\
\hline Litter size & 1 & $2.39 \pm 0.35$ & $2.43 \pm 0.23$ & 0.13 & 0.71 \\
\hline Litter birthdate & 1 & $141.83 \pm 1.06$ & $145.06 \pm 0.55$ & 7.49 & 0.006 \\
\hline \multicolumn{6}{|l|}{ SUGAR $(N=79)$} \\
\hline Change early to peak lactation ( $\mu \mathrm{g} / \mathrm{g}$ per day) & 1 & $0.32 \pm 0.07$ & $0.44 \pm 0.07$ & 0.91 & 0.34 \\
\hline Change peak to late lactation ( $\mu \mathrm{g} / \mathrm{g}$ per day) & 1 & $0.48 \pm 0.31$ & $0.90 \pm 0.18$ & 1.29 & 0.26 \\
\hline Litter size & 1 & $2.39 \pm 0.35$ & $2.43 \pm 0.23$ & 2.49 & 0.11 \\
\hline Litter birthdate & 1 & $141.83 \pm 1.06$ & $145.06 \pm 0.55$ & 2.11 & 0.15 \\
\hline \multicolumn{6}{|l|}{ ENERGY (N = 73) } \\
\hline Change early to peak lactation (kcal/g per day) & 1 & $0.03 \pm 0.005$ & $0.01 \pm 0.003$ & 3.49 & 0.06 \\
\hline Change peak to late lactation (kcal/g per day) & 1 & $-0.01 \pm 0.007$ & $-0.02 \pm 0.004$ & 3.47 & 0.06 \\
\hline Litter size & 1 & $2.39 \pm 0.35$ & $2.43 \pm 0.23$ & 1.09 & 0.30 \\
\hline Litter birthdate & 1 & $141.83 \pm 1.06$ & $145.06 \pm 0.55$ & 6.17 & 0.01 \\
\hline
\end{tabular}

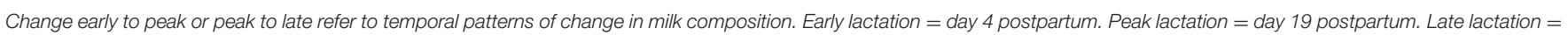

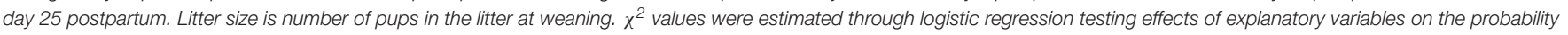
of juvenile survival. P-values shown in bold are statistically significant at an $\alpha$-level of 0.05 .
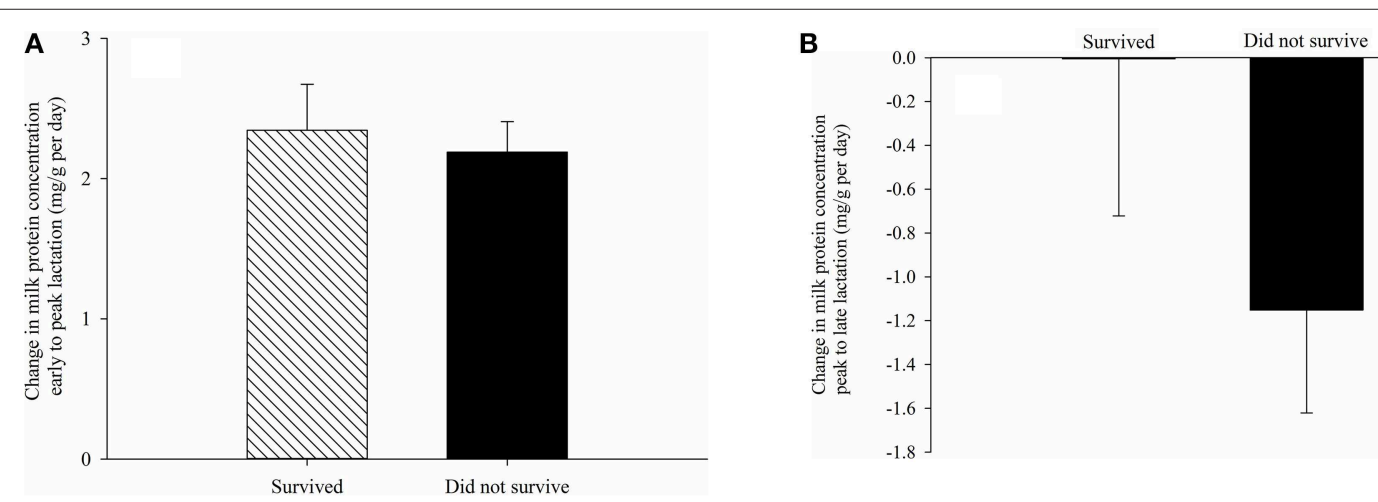

FIGURE 2 | Differences between mean changes in milk protein concentration from (A) early (day 4 postpartum) to peak lactation (day 19 postpartum) and (B) from peak to late lactation (day 25 postpartum) consumed by pups that survived and did not survive their first hibernation. Changes in milk composition reflect temporal variation within females (see Materials and Methods). Error bars are standard errors.

or mothers in better condition raise larger young by producing larger volumes of milk rather than higher quality milk (Kleiber, 1961; Oftedal, 1985; Landete-Castillejos et al., 2005). Holstein cows with greater body condition scores produce greater milk yields (Domecq et al., 1997) and heavier gray seal mothers with larger endogenous protein reserves have greater daily milk outputs (Mellish et al., 1999). Milk yield measurements are based on isotope dilution in the young, isotope transfer between the mother and offspring, or change in the mass of young following a suckling event (Hood et al., 2009). In all cases, access to the young is essential for completing these measurements. Because
Columbian ground squirrel pups reside in underground burrows until weaning, it was not possible to measure milk yield for this study.

Timing of reproduction impacts reproductive performance for many animals (Festa-Bianchet, 1988; Verhulst and Tinbergen, 1991; Dobson and Michener, 1995; Einum and Fleming, 2000) and may be especially critical for hibernating animals that need to gain fat mass prior to hibernation. By mating earlier, mothers and juveniles have more time to acquire fat reserves before hibernation commences (Murie and Boag, 1984; Millesi et al., 1999). We found that variation among female Columbian ground 
squirrels in the timing of parturition contributed to variation in milk fat and protein concentration and milk energy density. Although births spanned a period of only 3 weeks, females that gave birth near the beginning and the end of the birthing period had lower milk fat and energy density and higher protein content than females that gave birth around the mean parturition date. This phenomenon could arise if females giving birth around the mean litter birthdate entered peak lactation coinciding with the time when food resources have the greatest nutritive quality. Yet, this is not likely for our population as females giving birth around the mean litter birthdate would have been in peak lactation in mid-June and crude protein and digestibility of grasses and forbs on meadows in the Sheep River Provincial Park decline from about early June to mid-August (Bennett, 1999). Alternatively, adult females that reproduce earlier may restrain investment in high fat, energy dense milk as young may have adequate time to compensate post-weaning whereas females breeding later in the season may face constraints associated with the necessity to gain mass in preparation for hibernation (sensu Broussard et al., 2008). In Iberian red deer, hinds that were hormonally manipulated to calve earlier ("advanced hinds") in the season produced milk with lower fat concentration and a higher milk protein:fat ratio relative to hinds with standard calving dates (Gomez et al., 2002). Calves of both groups grew at similar rates during the lactation period, despite the differences in milk composition. However, calves born to artificially advanced hinds had faster growth rates post-weaning because of the longer time interval before the onset of winter (Gomez et al., 2002). Further, studies are required to determine if a similar scenario is occurring within Columbian ground squirrel populations.

A growing body of literature suggests that the composition of milk produced by mothers may vary with offspring sex. This relationship has been demonstrated in many species, including humans (Homo sapiens, Powe et al., 2010; Fujita et al., 2012), rhesus macaques (Macaca mulatta, Hinde, 2007a, 2009) red deer (Cervus elaphus hispanicus, Landete-Castillejos et al., 2005), and tammar wallabies (Macropus eugenii, Robert and Braun, 2012). A common trend in these studies is that milk composition, particularly fat, protein and/or energy density, tends to be higher in the milk of mothers nursing sons than in mothers nursing daughters. Furthermore, in some species there is an additive effect of offspring sex and maternal condition on milk synthesis. For example, primiparous rhesus macaque mothers rearing sons produce milk higher in energy than multiparous mothers and mothers of daughters due to higher milk fat and protein content (Hinde, 2007a, 2009). Primiparous mothers are often younger and have not yet achieved adult mass and thus may face tradeoffs between reproduction and somatic growth (Stearns, 1992). These relationships are likely to be much more complex in polytocous species where multiple young are produced at a time, but would be worthy of future exploration.

\section{Impacts of Milk Composition on Offspring}

The lack of association between milk composition and offspring weaning mass and mass gains in Columbian ground squirrels is surprising. Offspring mass and growth rates are correlated to milk composition in several mammals including gray seals (Iverson et al., 1993; Mellish et al., 1999), Iberian red deer (Landete-Castillejos et al., 2001; Gomez et al., 2002), and common marmosets (Tardif et al., 2001). Mass and growth, however, are dependent not only on milk composition, but also on lactation length (Mellish et al., 1999) and milk yield (Landete-Castillejos et al., 2003a; Hinde et al., 2009), which together determine the total amount of nutrients transferred during the lactation period, and the neonate's metabolic efficiency in converting nutrients and energy into mass (Mellish et al., 1999).

In Columbian ground squirrels, survival to yearling age is critical as most deaths occur during this time period (Bennett, 1999) and greater juvenile mass and growth rates are associated with a higher probability of survival through the first hibernation (Murie and Boag, 1984; Skibiel et al., 2009). We found that pups consuming milk with a greater daily increase in protein levels between early and peak lactation and with a lower rate of decline from peak to late lactation were more likely to survive overwinter. In other words, pups consuming milk that was relatively low in protein in early lactation but was relatively high in protein at peak and late lactation produced offspring that were more likely to survive overwinter. This pattern may reflect a female's capacity to adjust the composition of her milk throughout lactation in a manner that matches changing offspring developmental needs (Hood et al., 2009). Interestingly, the impact that milk composition has on overwinter survival does not appear to be due to effects on juvenile weaning mass or growth in body mass. Substantial tissue and organ development and functional maturation continues throughout postnatal life (Altman et al., 1970; Dobbing and Sands, 1979; Prykhodko et al., 2015) and are sensitive to nutrient intake during that time (Altman et al., 1970; Desai et al., 1996). It is possible that the protein content of milk at key points in development could impact offspring survival by contributing to structural changes in organ microanatomy and hence organ function. For example, in laboratory rats, prenatal and postnatal protein restriction affects renal and cardiovascular function through effects on the number of nephrons present in the kidneys and on mean arterial pressure (Hoppe et al., 2007).

Alternatively (or concomitantly), moderate changes in milk protein levels could influence offspring behavior. A recent study by Hinde and Capitanio (2010) show that milk composition, specifically available milk energy (the product of milk energy density and milk volume), impacts activity levels and temperament in infant rhesus macaques. Interestingly, higher available milk energy early in lactation is associated with higher activity levels and the display of more confident behaviors in infants several months later. Although there are no studies on the impact of milk protein levels per se on offspring behavior, experimental studies of dietary protein intake in laboratory rodents lend credence to the possibility of a link between the two. Dietary protein restriction of female mice during the period of oocyte maturation results in the production of more anxious offspring (Watkins et al., 2008). Moreover, laboratory rats fed a low protein diet are less responsive to a battery of behavioral assessment exercises and 
are more anxious (Onaivi et al., 1992). For juvenile Columbian ground squirrels, maternal effects occurring during the lactation period have significant effects on overwinter survival (Skibiel et al., 2009), but mass gain during the time of independent foraging post-weaning is also important for survival (Bennett, 1999). Higher activity levels of more confident, less anxious juvenile Columbian ground squirrels may be advantageous if they are associated with greater foraging rates prior to hibernation. Investigating effects of milk composition on juvenile physiology and behavior would be worthy endeavors for future research.

\section{Conclusion}

The timing of reproduction appears to be an important factor contributing to variation in milk composition as females that gave birth at either end of the birthing period produced milk with lower fat and energy density, but higher protein. Relatively higher levels of milk protein at peak and late lactation, promotes overwinter survival of juveniles. Reproducing earlier, however has been shown to have a positive effect on the probability of juvenile overwinter survival in this species (this study; Dobson et al., 1999; Neuhaus, 2000a), suggesting that despite the lower fat and energy of milk produced by earlier-breeding females, it is still advantageous to reproduce early. This may occur because young have more time post-weaning to forage independently and gain fat mass prior to hibernating. The results of this study underscore the need to examine the means through which maternal effects occur and their influences on fitness.

\section{References}

Altman, J., Das, G. D., and Sudarshan, K. (1970). The influence of nutrition on neural and behavioral development. I. Critical review of some data on the growth of the body and the brain following dietary deprivation during gestation and lactation. Dev. Psychobiol. 3, 281-301. doi: 10.1002/dev.4200 30408

Bennett, R. P. (1999). Effects of food quality on growth and survival of juvenile Columbian ground squirrels (Spermophilus columbianus). Can. J. Zool. 77, 1555-1561. doi: 10.1139/z99-144

Boag, D. A., and Murie, J. O. (1981). Population ecology of Columbian ground squirrels in southwestern Alberta. Can. J. Zool. 72, 2230-2240. doi: 10.1139/z81-302

Broussard, D. R., Dobson, F. S., and Murie, J. O. (2005). The effects of capital on an income breeder: evidence from female Columbian ground squirrels. Can. J. Zool. 83, 546-552. doi: 10.1139/z05-044

Broussard, D. R., Dobson, F. S., and Murie, J. O. (2008). Previous experience and reproductive investment of female Columbian ground squirrels. J. Mammal. 89, 142-152. doi: 10.1644/06-mamm-a-357.1

Clutton-Brock, T. H., Guinness, F. E., and Albo, S. D. (1982). Red Deer; Behavior and Ecology of Two Sexes. Chicago, IL: University of Chicago Press.

Cohen, D. (1976). The optimal timing of reproduction. Am. Nat. 110, 801-807. doi: $10.1086 / 283103$

de Moura, E. G., and Passos, M. C. F. (2005). Neonatal programming of body weight regulation and energetic metabolism. Biosci. Rep. 25, 251-269. doi: 10.1007/s10540-005-2888-3

Derrickson, E. M., Jerrard, N., and Oftedal, O. T. (1996). Milk composition of two precocial, arid-dwelling rodents, Kerodon rupestris and Acomys cahirinus. Physiol. Zool. 69, 1402-1418.

\section{Author Contributions}

WH and AS conceived, designed, and acquired funding for the study. AS collected samples and conducted analyses with the guidance of WH and wrote the manuscript. WH provided critical feedback for improvement of the manuscript. Both authors agree on the content and approve the manuscript.

\section{Acknowledgments}

We would like to thank all of the individuals and funding agencies who made this project possible, including funding through Auburn University College of Science and Mathematics (WH), an AU-CMB/NSF EPSCoR summer graduate research fellowship, Sigma Xi Grants-in-Aid of Research (G2009151040 and G200810150150) awarded to AS and by a National Science Foundation research grant to F.S. Dobson (DEB-0089473). Michael Power and Caitlin Power ran the CHN analyses at the Nutrition Laboratory of the Smithsonian Institution National Zoological Park, Paul Cobine provided access to and assistance with the ICP spectrometer, and Mark Liles permitted use of his ultraviolet spectrometer. Stephanie George provided invaluable assistance with sample collection in the field and many laboratory assistants in the WH laboratory, particularly Lauren Downing helped with milk assays. The University of Calgary Biogeoscience (BGS) Institute provided housing in the field at the R. B. Miller Field Station. We would like to especially thank Ed Johnson, the BGS Institute director, Kathreen Ruckstuhl, the BGS Institute associate director, and Judy Buchanin-Mappin, the BGS Institute research services coordinator.

Desai, M., Crowther, N. J., Lucas, A., and Hales, C. N. (1996). Organ-selective growth in the offspring of protein-restricted mothers. Br. J. Nutr. 76, 591-603. doi: 10.1079/BJN19960065

de Souza Caldeira Filho, J., and Moura, A. S. (2000). Undernutrition during early lactation period induces metabolic imprinting leading to glucose homeostasis alteration in aged rats. Res. Commun. Mol. Pathol. Pharmacol. 108, 213-226.

Dewey, K. G. (1997). Energy and protein requirements during lactation. Annu. Rev. Nutr. 17, 19-36. doi: 10.1146/annurev.nutr.17.1.19

Dobbing, J., and Sands, J. (1979). Comparative aspects of the brain growth spurt. Early Hum. Dev. 311, 79-83. doi: 10.1016/0378-3782(79)90022-7

Dobson, F. S., Badry, M. J., and Geddes, C. (1992). Seasonal activity and body mass of Columbian ground squirrels. Can. J. Zool. 70, 1364-1368. doi: 10.1139/ z92-192

Dobson, F. S., and Kjelgaard, J. D. (1985). The influence of food resources on life history in Columbian ground squirrels. Can. J. Zool. 63, 2105-2109. doi: 10.1139/z85-309

Dobson, F. S., and Michener, G. R. (1995). Maternal traits and reproduction in Richardson's ground squirrels. Ecology. 76, 851-862. doi: 10.2307/1939350

Dobson, F. S., and Murie, J. O. (1987). Interpretation of intraspecific life history patterns evidence from Columbian ground squirrels. Am. Nat. 129, 382-397. doi: $10.1086 / 284643$

Dobson, F. S., Risch, T. S., and Murie, J. O. (1999). Increasing returns in the life history of Columbian ground squirrels. J. Anim. Ecol. 68, 73-86. doi: 10.1046/j.1365-2656.1999.00268.x

Domecq, J. J., Skidmore, A. L., Lloyd, J. W., and Kaneene, J. B. (1997). Relationship between body condition scores and milk yield in a large dairy herd of high yielding Holstein cows. J. Dairy Sci. 80:101-112. doi: 10.3168/jds.S00220302(97)75917-4 
Donohue, K., and Schmitt, J. (1998). "Maternal environmental effects in plants: adaptive plasticity?" in Maternal Effects as Adaptations, eds T. A. Mousseau and C. W. Fox (New York, NY: Oxford University Press), 137-158.

Doreau, M., Boulot, S., Bauchart, D., Barlet, J.-P., and Martin-Rosset, W. (1992). Voluntary intake, milk production and plasma metabolites in nursing mares fed two different diets. J. Nutr. 122, 992-999.

Drent, R. H., and Daan, S. (1980). The prudent parent: energetic adjustments in avian breeding Ardea 68, 225-252.

Einum, S., and Fleming, I. A. (2000). Selection against late emergence and small offspring in atlantic salmon (Salmo salar). Evolution 54, 628-639. doi: 10.1111/j.0014-3820.2000.tb00064.x

Festa-Bianchet, M. (1988). Birthdate and survival in bighorn lambs (Ovis canadensis). J. Zool. 214, 653-661. doi: 10.1111/j.1469-7998.1988.tb03764.x

Fox, C. W., and Mousseau, T. A. (1998). "Maternal effects as adaptations for transgenerational phenotypic plasticity in insects," in Maternal Effects as Adaptations, eds T. A. Mousseau and C. W. Fox (New York, NY: Oxford University Press), 159-177.

Fujita, M., Roth, E., Lo, Y.-J., Hurst, C., Vollner, J., and Kendell, A. (2012). In poor families, mothers' milk is richer for daughters than sons: a test of TriversWillard hypothesis in agropastoral settlements in northern Kenya. Am. J. Phys. Anthropol. 149, 52-59. doi: 10.1002/ajpa.22092

Georges, J.-Y., Groscolas, R., Guinet, C., and Robin, J. P. (2001). Milking strategy in subantarctic fur seals Arctocephalus tropicalis breeding on Amsterdam island: evidence from changes in milk composition. Physiol. Biochem. Zool. 74, 548-559. doi: 10.1086/322164

Gluckman, P. D., Hanson, M. A., and Spencer, H. G. (2005). Predictive adaptive responses and human evolution. Trends Ecol. Evol. 20, 527-533. doi: 10.1016/j.tree.2005.08.001

Gomez, J. A., Landete-Castillejos, T., Garcia, A., and Gallego, L. (2002). Effect of calving advance on milk production and composition, and calf growth in Iberian deer (Cervus elaphus hispanicus). Small Ruminant Res. 44, 213-218. doi: 10.1016/S0921-4488(02)00078-0

Hinde, K. (2007a). First-time macaque mothers bias milk composition in favor of sons. Curr. Biol. 17, R958-R959. doi: 10.1016/j.cub.2007.09.029

Hinde, K. (2007b). Milk composition varies in relation to the presence and abundance of Balantidium coli in the mother in captive Rhesus macaques (Macaca mulatta). Am. J. Primatol. 69, 625-634. doi: 10.1002/ajp. 20373

Hinde, K. (2009). Richer milk for sons but more milk for daughters: sexbiased investment during lactation varies with maternal life history in Rhesus Macaques. Am. J. Hum. Biol. 21, 512-519. doi: 10.1002/ajhb.20917

Hinde, K., and Capitanio, J. P. (2010). Lactational programming? Mother's milk energy predicts infant behavior and temperament in Rhesus macaques (Macaca mulatta). Am. J. Primatol. 72, 522-529. doi: 10.1002/ajp.20806

Hinde, K., Power, M. L., and Oftedal, O. T. (2009). Rhesus macaque milk: magnitude, sources, and consequences of individual variation over lactation. Am. J. Phys. Anthropol. 138, 148-157. doi: 10.1002/ajpa.20911

Holekamp, K. E., and Dionak, S. M. (2009). "Maternal effects in fissiped carnivores," in Maternal Effects in Mammals, eds D. Maestripieri and J. M. Mateo (Chicago, IL: The University of Chicago Press), 227-255.

Hood, W. R., Voltura, M. B., and Oftedal, O. T. (2009). "Methods of measuring milk composition and yield in small mammals," in Ecological and Behavioral Methods for the Study of Bats, eds T. H. Kunz and S. Parsons (Baltimore, MD: John Hopkins University Press), 529-553

Hoogland, J. L. (1995). The Black-tailed Prairie Dog. Chicago, IL: University of Chicago Press.

Hoppe, C. C., Evans, R. G., Moritz, K. M., Cullen-McEwen, L. A., Fitzgerald, S. M., Dowling, J., et al. (2007). Combined prenatal and postnatal protein restriction influences adult kidney structure, function, and arterial pressure. Am. J. Physiol. Regul. Integr. Comp. Physiol. 292, R462-R469. doi: 10.1152/ajpregu.00079.2006

Huber, S., Millesi, E., Walzl, M., Dittami, J., and Arnold, W. (1999). Reproductive effort and costs of reproduction in female European ground squirrels. Oecologia 121, 19-24. doi: 10.1007/s004420050902

Iverson, S. J., Bowen, W. D., Boness, D. J., and Oftedal, O. T. (1993). The effect of maternal size and milk energy output on pup growth in grey seals (Halichoerus grypus). Physiol. Zool. 66, 61-88.

Jönsson, K. I. (1997). Capital and income breeding as alternative tactics of resource use in reproduction. Oikos 78, 57-66. doi: 10.2307/3545800
King, W. J., Festa-Bianchet, M., and Hatfield, S. E. (1991). Determinants of reproductive success in female Columbian ground squirrels. Oecologia 86, 528-534. doi: 10.1007/BF00318319

Kirkpatrick, M., and Lande, R. (1989). The evolution of maternal characters. Evolution 43, 485-503. doi: 10.2307/2409054

Kleiber, M. (1961). The Fire of Life: an Introduction to Animal Energetics. New York, NY: Wiley.

Lande, R., and Kirkpatrick, M. (1990). Selection response in traits with maternal inheritance. Genet. Res. 55, 189-197. doi: 10.1017/S0016672300025520

Landete-Castillejos, T., Molina, A. P., García, A., Gómez, J. A., and Gallego, L. (2003b). Estimate and production of milk energy in two subspecies of captive red deer: Cervus elaphus and C. e. scoticus. J. Exp. Zool. 300A, 152-157. doi: 10.1002/jez.a. 10320

Landete-Castillejos, T., García, A., and Gallego, L. (2001). Calf growth in captive Iberian red deer (Cervus elaphus hispanicus): effect of birth date and hind milk production and composition. J. Anim. Sci. 79, 1085-1092.

Landete-Castillejos, T., García, A., Gómez, J. A., and Gallego, L. (2003a). Lactation under food constraints in Iberian red deer Cervus elaphus hispanicus. Wildlife Biol. 9, 131-139.

Landete-Castillejos, T., García, A., López-Serrano, F. R., and Gallego, L. (2005). Maternal quality and differences in milk production and composition for male and female Iberian red deer calves (Cervus elaphus hispanicus). Behav. Ecol. Sociobiol. 57, 267-274. doi: 10.1007/s00265-004-0848-8

Maestripieri, D., and Mateo, J. M. (2009). "The role of maternal effects in mammalian evolution and adaptation," in Maternal Effects in Mammals, eds. D. Maestripieri and J. M. Mateo (Chicago, IL: The University of Chicago Press), $1-10$.

McMillen, I. C., and Robinson, J. S. (2005). Developmental origins of the metabolic syndrome: prediction, plasticity, and programming. Physiol. Rev. 85, 571-633. doi: 10.1152/physrev.00053.2003

Mellish, J. A., Iverson, S. J., and Bowen, W. D. (1999). Variation in milk production and lactation performance in grey seals and consequences for pup growth and weaning characteristics. Physiol. Biochem. Zool. 72, 677-690. doi: $10.1086 / 316708$

Millesi, E., Huber, S., Everts, L., and Dittami, J. (1999). Reproductive decisions in female European ground squirrels: factors affecting reproductive output and maternal investment. Ethology 105, 163-175. doi: 10.1046/j.14390310.1999.00379.x

Murie, J. O. (1992). Predation by badgers on Columbian ground squirrels. J. Mammal. 73, 385-394. doi: 10.2307/1382073

Murie, J. O., and Boag, D. A. (1984). The relationship of body weight to overwinter survival in Columbian ground squirrels. J. Mammal. 65, 688-690. doi: $10.2307 / 1380854$

Murie, J. O., and Harris, M. A. (1982). Annual variation of spring emergence and breeding in Columbian ground squirrels (Spermophilus columbianus). J. Mammal. 63, 431-439. doi: 10.2307/1380440

Murie, J. O., and Harris, M. A. (1984). "The history of individuals in a population of Columbian ground squirrels: source settlement and site attachment," in The Biology of Ground-dwelling Squirrels, eds J. O. Murie and G. R. Michener (Nebraska, NE: University of Nebraska Press), 353-373.

Murie, J. O., Stevens, S. D., and Leoppky, B. (1998). Survival of captive-born cross-fostered juvenile Columbian ground squirrels in the field. J. Mammal. 79, 1152-1160. doi: 10.2307/1383006

Neuhaus, P. (2000a). Timing of hibernation and molt in female Columbian ground squirrels. J. Mammal. 81, 571-577. doi: 10.1644/1545-1542(2000)081<0571:TOHAMI >2.0.CO;2

Neuhaus, P. (2000b). Weight comparisons and litter size manipulation in Columbian ground squirrels (Spermophilus columbianus) show evidence of costs of reproduction. Behav. Ecol. Sociobiol. 48, 75-83. doi: $10.1007 / \mathrm{s} 002650000209$

Nommsen, L. A., Lovelady, C. A., Heinig, M. J., Lönnerdal, B., and Dewey, K. G. (1991). Determinants of energy, protein, lipid, and lactose concentrations in human milk during the first 12 mo of lactation: the DARLING study. Am. J. Clin. Nutr. 53, 457-465.

Oftedal, O. T. (1985). "Pregnancy and lactation," in Bioenergetics of Wild Herbivores, eds R. J. Hudson and R. G. White (Boca Raton, FL: CRC), 215-238.

Onaivi, E. S., Brock, J. W., and Prasad, C. (1992). Dietary protein levels alter rat behavior. Nutr. Res. 12, 1025-1039. doi: 10.1016/S0271-5317(05)80586-X 
Powe, C. E., Knott, C. D., and Conklin-Brittain, N. (2010). Infant sex predicts breast milk enery content. Am. J. Hum. Biol. 22, 50-54. doi: 10.1002/ajhb.20941

Powell, R. A., Zimmerman, J. W., and Seaman, D. E. (1997). Ecology and Behaviour of North American Black Bears: Home Ranges, Habitat, and Social Organization. New York, NY: Chapman \& Hall.

Prentice, A. (2004). Diet, nutrition and the prevention of osteoporosis. Public Health Nutr. 7, 227-243. doi: 10.1079/PHN2003590

Price, T. (1998). "Maternal and paternal effects in birds," in Maternal Effects as Adaptations, eds T. A. Mousseau and C. W. Fox (New York, NY: Oxford University Press), 202-226.

Prykhodko, O., Pierzynowski, S. G., Nikpey, E., Sureda, E. A., Fedkiv, O., and Weström, B. R. (2015). Pancreatic and pancreatic-like microbial proteases accelerate gut maturation in neonatal rats. PLOS ONE 10:e0116947. doi: 10.1371/journal.pone.0116947

Racey, P. A., and Entwistle, A. C. (2000). "Life-history and reproductive strategies of bats," in Reproductive Biology of Bats, eds E. G. Chrichton and P. H. Krutzsch (San Diego, CA: Academic Press), 363-414.

Ralls, K. (1976). Mammals in which females are larger than males. Q. Rev. Biol. 51, 245-276. doi: 10.1086/409310

Rieger, J. F. (1996). Body size, litter size, timing of reproduction, and juvenile survival in the Uinta ground squirrel, Spermophilus armatus. Oecologia 107, 463-468. doi: 10.1007/BF00333936

Robbins, C. T., Podbielancik-Norman, R. S., Wilson, D. L., and Mould, E. D. (1981). Growth and nutrient consumption of elk calves compared to other ungulate species. J. Wildl. Manage. 45, 172-186. doi: 10.2307/3807885

Robert, K. A., and Braun, S. (2012). Milk composition during lactation suggests a mechanism for male biased allocation of maternal resources in the tammar wallaby (Macropus eugenii). PLoS ONE 7, 1-6. doi: 10.1371/journal.pone.0051099

SAS. (2002). SAS v.9.1.3 for Windows. Cary, NC: SAS Institute Inc.

Schulte-Hostedde, A. I., Zinner, B., Millar, J. S., and Hickling, G. J. (2005). Restitution of mass-size residuals: validating body condition indices. Ecology 86, 155-163. doi: 10.1890/04-0232

Serkova, N. J., Rose, J. C., Epperson, L. E., Carey, H. V., and Martin, S. L. (2007). Quantitative analysis of liver metabolites in three stages of the circannual hibernation cycle in 13-lined ground squirrels by NMR. Physiol. Genomics. 31, 15-24. doi: 10.1152/physiolgenomics.00028.2007

Shaw, W. T. (1925). Breeding and development of the Columbian ground squirrel. J. Mammal. 6, 106-113. doi: 10.2307/1373385

Skibiel, A. L., Dobson, F. S., Murie, J. O. (2009). Maternal influences on reproduction in two populations of Columbian ground squirrels. Ecol. Monogr. 79, 325-341. doi: 10.1890/08-0718.1
Skibiel, A. L., and Hood, W. R. (2013). Milk composition in a hibernating rodent, the Columbian ground squirrel (Urocitellus columbianus). J. Mammal. 94, 146-154. doi: 10.1644/1-MAMM-A-078.1

Skibiel, A. L., Speakman, J. R., and Hood, W. R. (2013). Testing the prediction of energy allocation decisions in the evolution of life-history trade-offs. Funct. Ecol. 27, 1382-1391. doi: 10.1111/1365-2435.12130

Stearns, S. C. (1992). The Evolution of life Histories. (New York, NY: Oxford University Press).

Tahti, H. (1978). Seasonal differences in the $\mathrm{O}_{2}$ consumption and respiratory quotient in a hibernator (Erinaceus europeaus L). Ann. Zool. Fenn. 15, 69-75.

Tardif, S. D., Power, M., Oftedal, O. T., Power, R. A., and Layne, D. G. (2001). Lactation, maternal behavior and infant growth in common marmoset monkeys (Callithrix jacchus): effects of maternal size and litter size. Behav. Ecol. Sociobiol. 51, 17-25. doi: 10.1007/s002650100400

Verhulst, S., and Tinbergen, J. M. (1991). Experimental evidence for a causal relationship between timing and success of reproduction in the great tit Parus m. major. J. Anim. Ecol. 60, 269-282. doi: 10.2307/5459

Watkins, A. J., Wilkins, A., Cunningham, C., Perry, V. H., Seet, M. J., Osmond, C., et al. (2008). Low protein diet fed exclusively during mouse oocyte maturation leads to behavioural and cardiovascular abnormalities in offspring. J. Physiol. 586, 2231-2244. doi: 10.1113/jphysiol.2007.149229

Wells, J. C. K. (2007). Flaws in the theory of predictive adaptive responses. Trends Endocrinol. Metab. 18, 331-337. doi: 10.1016/j.tem.2007. 07.006

Wolf, J. B., Brodie, E. D., Cheverud, J. M., Moore, A. J., and Wade, M. J. (1998). Evolutionary consequences of indirect genetic effects. Trends Ecol. Evol. 13, 64-69. doi: 10.1016/S0169-5347(97)01233-0

Young, P. J. (1990). Hibernating patterns of free-ranging Columbian ground squirrels. Oecologia 83, 504-511. doi: 10.1007/BF003 17201

Conflict of Interest Statement: The authors declare that the research was conducted in the absence of any commercial or financial relationships that could be construed as a potential conflict of interest.

Copyright (c) 2015 Skibiel and Hood. This is an open-access article distributed under the terms of the Creative Commons Attribution License (CC BY). The use, distribution or reproduction in other forums is permitted, provided the original author(s) or licensor are credited and that the original publication in this journal is cited, in accordance with accepted academic practice. No use, distribution or reproduction is permitted which does not comply with these terms. 